\title{
遠心脱水による細骨材の表面乾燥飽水状態について

\author{
ON THE SATURATED SURFACE-DRY CONDITION OF \\ FINE AGGREGATE BY CENTRIFUGAL DEHYDRATION
}

\author{
吉 兼 烹* - 中島 佳 郎** \\ By Tohru YOSHIKANE and Yoshiroh NAKASHIMA
}

\begin{abstract}
The saturated surface-dry condition of fine aggregate has been obtained usually by the flow-cone method. However, we have indicated that this method is so sensible for judgement that the individual difference is large. Then we studied in the method of preparing the saturated surface-dry condition mechanically by utilizing centrifugal dehydration. It has been found that the percentage of water content at the inflection point of the dehydration curve on a certain dehydration condition closely resembles it of water absorption by the flow-cone method. According to the kinds of fine aggregate, the percentage of water absorption in the saturated surface-dry condition, which is prepared on the constant dehydoration condition, closely resembles it of water absorption prepared by the flow-cone method and its experimental or personal error is far smaller than it of the flow-cone method.
\end{abstract}

Keywords : fine aggregate, saturated surface-dry condition, percentage of water absorption, centrifugal dehydration

\section{1. まえがき}

細骨材の表面乾燥飽水状態（以下, 表乾状態）は JIS A 1109「細骨材の比重及び吸水率試験方法」でフローコー ンによる方法 (以下, フロー方法) で求めることとなっ ている.しかし，この方法では測定者の感覚的判断が伴 う面もあるため测定者間の個人差が大きい.また，細骨 材の性状のうち洗い試験で失われる量（以下，洗い損失 量) の多いもの, すなわち石粉, シルト, 粘土粒子等を 多く含むもの, 多孔質なもの, 鋭い稜角の粒子に富んだ もの等への適用には問題が少なくない. またそのため表 乾状態の不安定さは比重および吸水率の試験誤差ともな り, 骨材の品質判定やコンクリートの配合における単位 水量の值にも影響を与える. そこで, 著者らは遠心脱水 機を用いた方法（以下，遠心方法）により，湿潤細骨材 を機械的に表乾状態とするための実験を行った結果, 遠 心力, 脱水時間等の条件を細骨材の種類に応じて一定に すれば，細骨材を機械的に表乾状態となし得ることを見

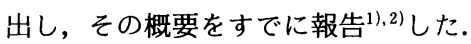

このほか遠心力を利用したものとして細骨材の表面吸
着水を求めた伊東の報告 ${ }^{3)}$ ， セメントあるいは微粉末 のペースト中に分散させた細骨材の保有水試験方法につ いての辻らの提案“)があるが, 著者らの研究はあくまで も細骨材のフロー方法による表乾状態の判定における感 覚的判断に基づく個人差を排除することを目的としてお り，湿潤細骨材を機械的方法で脱水し，フロ一方法で求 めた吸水率の值に近似する表乾状態への試料の調整方法 の提案である.

本研究は, 先の報告 ${ }^{1), 2)}$ で用いた遠心分離機では, 十 分なレベルの遠心力を用い得なかったことから，細骨材 の試料ごとに脱水条件をあらかじめ予備実験により決め ておく必要があったこと，1度に調整できる試料の量が 1 回の比重試験に用いる量に満たなかったことなどの問 題点の解決のため, 新たに別の構造の遠心脱水機を用い て実験を行った。その結果細骨材の種類（普通骨材およ び砕砂, スラグ細骨材, 人工軽量細骨材の 4 種類) ごと に，一定の脱水条件で脱水を行うことにより試料を表乾 状態に調整し得ることと，この方法により調整した試料 による吸水率の試験では個人差がフロー方法によるもの に比べて著しく小さくなることが確認できた.

\footnotetext{
* 正会員 大有建設(株)中央研究所所長 ( 个454 名古屋市中川区十番町 6-12)

** 大有建設(株)中央研究所研究員 (同上)
} 


\section{2. 実験の概要}

\section{（1）実験の方法}

a) 遠心脱水機

実験には市販の遠心脱水機（Photo1参照）を用い Fig. 1 に示すように，底部に排水孔 $(\phi 5 \mathrm{~mm})$ をあけた 内径 $65 \mathrm{~mm}$ ，深さ $130 \mathrm{~mm}$ ，内容積約 $425 \mathrm{~m} l$ の金属製 試料カップ 4 個掛け, 試料重心位置の半径約 $219 \mathrm{~mm}$, 回転数はおおよそ $600 \sim 3900 \mathrm{rpm}\left(10 \mathrm{~s}^{-1} \sim 65 \mathrm{~s}^{-1}\right)$ の 可変型で，これにより試料中心部の遠心力はおよそ 100 〜3500 g の範囲内で任意に選べるものである.なお高 い遠心力での脱水時間が長くなるとモータ一からの発 熱，および回転する試料カップと脱水機槽内の空気との 摩擦による発熱加らの試料の乾燥を防ぐ目的で, 外槽を 送風ファンにより空冷した。また，前記実験 ${ }^{1,2)}$ および 本実験の予備実験の結果を検討し, 試料内の空気の移動 を遮断し乾燥を防ぐために硬質スポンジによる落し蓋を 用いた。

沪布には JIS 規格のような標準規格はないので，メー カー規格によることとし, A タイプは通気度 $20 \sim 25$ $\mathrm{cm} / \mathrm{s}$, 厚さ $1.1 \mathrm{~mm}$, 綾織り, 系の太さ 800 デニール,

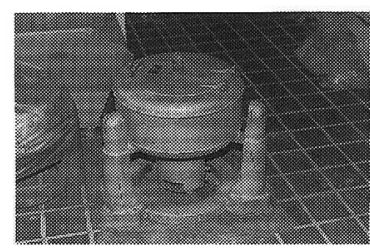

(a) External appearance

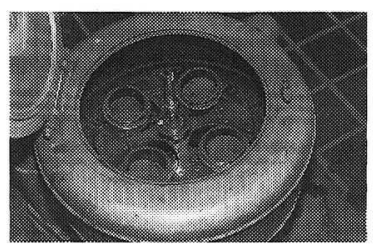

(b) Sample cup in the cover

Photo1 Centrifugal equipment and sample cup.

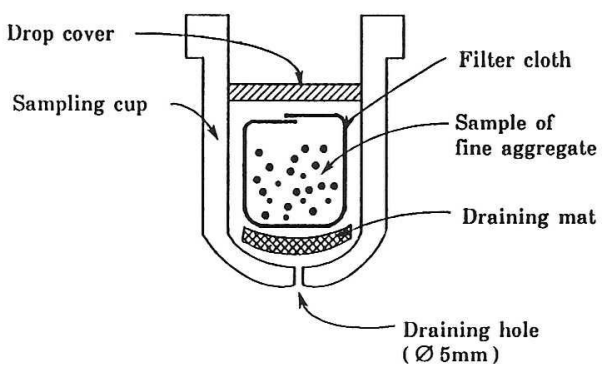

Fig. 1 Section of sample cup.
重量 $540 \mathrm{~g} / \mathrm{m}^{2} ，$ ポリプロピレン製および，B夕イプは 通気度 $15-8 \mathrm{~cm} / \mathrm{s}$, 厚さ $0.9 \mathrm{~mm}$, 綾織り, 糸の太さ 342 デニール 2 本より, 重量 $440 \mathrm{~g} / \mathrm{m}^{2}$, ポリプロピレン 製の 2 種類を用いた。

また試料カップ内底の水の移動をよくするため厚さ約 $4 \mathrm{~mm}$ ，約 $\phi 60 \mathrm{~mm}$ の不織布（ポリプロピレン製）の排 水マットを武料カップ内に敷いた。

b) 実験方法

実験は各細骨材ごとにフロー方法により表乾状態に調 整した試料で求めた吸水率（以下，フロー吸水率）と， 遠心脱水を行った試料で求めた含水率（以下，遠心含水 率）とを求めた。なお，遠心含水率は次の手順で求めた。

\section{試験の手順}

(1) 試料の細骨材は JIS A 1109 3. 試料の 3.1 に従っ て 24 時間吸水後のものを用いる.

(2) 試料カップの底にあらかじめ排水マットを敷く.

(3) 試料の初期含水状態の調整および計量

沪布を水に十分に浸した後,試料カップに入れて, 遠心力が $100 \mathrm{~g}$ に相当する回転数で 1 分間脱水する （脱水時間は回転のスタートからの時間をいう．以 下同樣).

次に沪布をつけたまま試料カップをはかりに乗 せ, 所定の質量より 10 数 $\mathrm{g}$ 程度多い試料を沪布内 に計り取る.この試料カップを遠心脱水機に装着し， 遠心力が $100 \mathrm{~g}$ となるような回転数を与えて 1 分間 の予備脱水し, 再びカップを取り出しはかりに乗せ て試料の質量が所定の質量 $\pm 1 \mathrm{~g}$ となるよう計り取 る（試料の初期含水率が大幅に異なると，脱水によ る試料カップ内の試料の容積変化をもたらし, 試料 の重心位置までの回転半径が一様でなくなり試験誤 差が大きくなるのを防ぐため).

(4) 遠心脱水

試料カップ内の沃布上部の余剩部分を内側に折り 畳むように閉じ，さらに落し蓋を挿入し所定の遠心 力に相当する回転数で所定時間の遠心脱水を行う.

（5）遠心脱水機を停止後，ただちに試料を沪布から取 り出しその質量を $0.01 \mathrm{~g}$ まで計るとともに，その 試料の乾燥質量とから遠心含水率を次式により求め る.

$$
\begin{aligned}
& P(\%)=\frac{W_{S}-W_{D}}{W_{D}} \times 100 \\
& \text { ここに, } P(\%): \text { 遠心含水率 } \\
& W_{S}: \text { 遠心脱水後の試料の質量 }(\mathrm{g}) \\
& W_{D}: \text { 乾燥後の試料の質量 }(\mathrm{g})
\end{aligned}
$$

（6）沪布は軽く水洗い後同じ操作を繰り返す．作業を 終了するときは沪布を乾燥して保管する。

（7) 新しい沪布を使用する場合は，上記の(2)～(4)操作 
Table 1 Types and properties of fine aggregate.

\begin{tabular}{|c|c|c|c|c|c|c|c|c|}
\hline \multirow{2}{*}{ Type } & \multirow{2}{*}{$\begin{array}{l}\text { Place or brand } \\
\text { of production }\end{array}$} & \multirow{2}{*}{ Mark } & \multirow{2}{*}{$\begin{array}{l}\text { Fineness } \\
\text { modulus } \\
\text { (F.M.) }\end{array}$} & \multirow{2}{*}{$\begin{array}{c}\text { Amount of } \\
\text { material passing } \\
\text { by washing } 1)(\%) \\
\end{array}$} & \multirow{2}{*}{$\begin{array}{l}\text { Unit weight } \\
(\mathrm{kg} / \mathrm{e})\end{array}$} & \multirow{2}{*}{$\begin{array}{c}\left.\begin{array}{c}\text { percentage of } \\
\text { absolute } \\
\text { volume }\end{array}\right)(\%) \\
\end{array}$} & \multicolumn{2}{|c|}{ Specific gravity ${ }^{3)}$} \\
\hline & & & & & & & $\begin{array}{c}\text { Saturated surface- } \\
\text { dry condition }\end{array}$ & $\begin{array}{c}\text { absolute } \\
\text { dry condition }\end{array}$ \\
\hline River sand & Machiya river & A 1 & 2.94 & 1.6 & 1.660 & 65.4 & 2.59 & 2.54 \\
\hline Pit sand & $\begin{array}{c}\text { Tado } \\
\text {, }\end{array}$ & $\begin{array}{l}\text { C } 1 \\
\text { C } 2\end{array}$ & $\begin{array}{l}2.65 \\
2.65\end{array}$ & $\begin{array}{l}3.0 \% \\
1.5\end{array}$ & $\begin{array}{l}1.642 \\
1.595\end{array}$ & $\begin{array}{l}65.9 \\
63.8\end{array}$ & $\begin{array}{l}2.54 \\
2.54\end{array}$ & $\begin{array}{l}2.49 \\
2.50\end{array}$ \\
\hline Crushed sand & $\begin{array}{c}\text { Suga island } \\
\text { Utsutsu } \\
\\
"\end{array}$ & $\begin{array}{l}\text { F } 1 \\
\text { G } 1 \\
\text { G } 2 \\
G 3 \\
\text { G } 4\end{array}$ & $\begin{array}{l}2.82 \\
2.53 \\
2.54 \\
2.62 \\
2.63\end{array}$ & $\begin{array}{l}4.4 \\
8.8 \% \\
6.2 \% \\
3.8 \% \\
0.6 \%\end{array}$ & $\begin{array}{l}1.682 \\
1.537 \\
1.590 \\
1.625 \\
1.663\end{array}$ & $\begin{array}{l}60.5 \\
60.5 \\
62.1 \\
63.2 \\
64.0\end{array}$ & $\begin{array}{l}2.82 \\
2.60 \\
2.60 \\
2.60 \\
2.62\end{array}$ & $\begin{array}{l}2.78 \\
2.54 \\
2.56 \\
2.57 \\
2.60\end{array}$ \\
\hline $\begin{array}{l}\text { Artificial light weight } \\
\text { fine aggregate }\end{array}$ & Mesalite & H 1 & 2.67 & 6.1 & 1.159 & 70.7 & 1.90 & 1.64 \\
\hline Slag fine aggregate & Shinnittetsu & 11 & 2.45 & 3.5 & 1.525 & 59.6 & 2.61 & 2.54 \\
\hline
\end{tabular}

Notes: 1) Values attached $※$ show adjusting the amount of material passing by washing of sample.

2) Values were obtained by the gradation as it is.

3) Experimental adjustment by flow method.

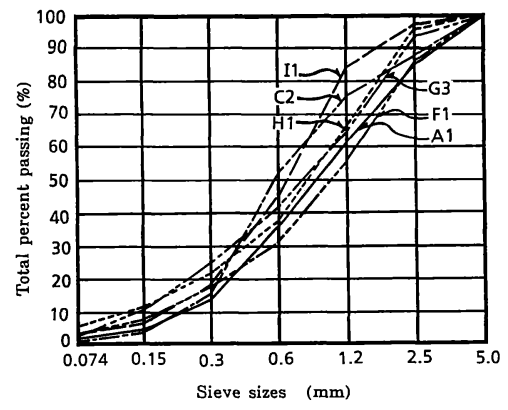

Fig. 2 Grading of fine aggregate.

を実際に調整の対象となる試料を用いて予備的に

2,3 回繰り返してから, 本操作を行うこととする.

（2）使用材料

実験に用いた細骨材の種類および性状を Table 1 に, その粒度分布を Fig. 2 に示す.

細骨材のうちでも洗い損失量については, 一部の細骨 材を対象に, JIS A 5308 の付属書または土木学会コン
クリート標準示方書に定められている基準值などの上限 值程度のもの, および上限值の $2 / 3 \sim 1 / 2$ 程度のものな に゙を目安に，室内で調整して試料とした。

\section{3. フロー吸水率のばらつき}

試験結果にばらつきの生ずる要素としては, 一人の試 験者が同じ試料で数多く繰り返し試験を行った際の試験 結果の值に生ずるばらつき(ここでは再現性のばらつき とよぶ）と, 同一試料を用いるが異なった試験者が同じ 試験を行った際の試験結果の值に生ずるばらつき（ここ では個人差とよぶ）とがあり，実際にはこれらが複合さ れて試験結果のばらつきとなる.

フロー吸水率におけるこれらのばらつきに関しての報 告が見当たらないところから，これらのばらつきを把握 する目的で行ったフロー吸水率の試験結果の一例を Table 2 に示し, この試験を各種の細骨材について行っ た結果を要約して Fig. 3 に示した。なお，この試験に用 いた細骨材の試料は, 4. 以下の本研究における実験に

Table 2 An example of reproducibility and personal differencies in percentage of water absorption by flow method. Kind of fine aggregate : River sand ,Specific gravity 2.54 , Finenens modulus $3.05,0.075 \mathrm{~mm}$ passing 1.76

\begin{tabular}{|c|c|c|c|c|c|c|c|c|c|c|c|c|c|}
\hline \multirow{2}{*}{\multicolumn{2}{|c|}{$\begin{array}{r}\begin{array}{r}\text { Personal } \\
\text { differencies }\end{array} \\
\text { Reprod. } \\
\text { ucibility }\end{array}$}} & \multicolumn{6}{|c|}{ Inspecter } & \multirow{2}{*}{ Average } & \multirow{2}{*}{$\begin{array}{l}\text { Maxim- } \\
\text { um value }\end{array}$} & \multirow{2}{*}{$\begin{array}{l}\text { Minim- } \\
\text { um value }\end{array}$} & \multirow{2}{*}{ Range } & \multirow{2}{*}{$\begin{array}{l}\text { Standard } \\
\text { deviation }\end{array}$} & \multirow{2}{*}{$\begin{array}{c}\text { ※ } \\
95 \% \text { con- } \\
\text { fidence } \\
\text { interval }\end{array}$} \\
\hline & & A & B & C & D & $\mathbf{E}$ & $\mathbf{F}$ & & & & & & \\
\hline \multicolumn{2}{|c|}{ Average } & 1.563 & 1.587 & 1.585 & 1.573 & 1.493 & 1.465 & 1.544 & 1.648 & 1.433 & 0.215 & 0.085 & \pm 0.166 \\
\hline \multicolumn{2}{|c|}{ Maximum value } & 1.70 & 1.66 & 1.70 & 1.77 & 1.63 & 1.53 & 1.665 & \multirow{3}{*}{\multicolumn{5}{|c|}{ Average }} \\
\hline \multicolumn{2}{|c|}{ Minimum value } & 1.44 & 1.48 & 1.47 & 1.40 & 1.38 & 1.40 & 1.428 & & & & & \\
\hline \multicolumn{2}{|c|}{ Range } & 0.26 & 0.18 & 0.23 & 0.37 & 0.25 & 0.13 & 0.237 & & & & & \\
\hline
\end{tabular}

Notes: 1) Each result shows average of two measurements (On the basis of JIS A 1109 or 1134)

2 ) ※ denotes the $95 \%$ confidence interval of single sampling from the population estimated from six test results respectively. ( test of JIS A 1109 or 1134 does not show a repeatable average but one test result (average of two measurements), hence we do it like this .) 


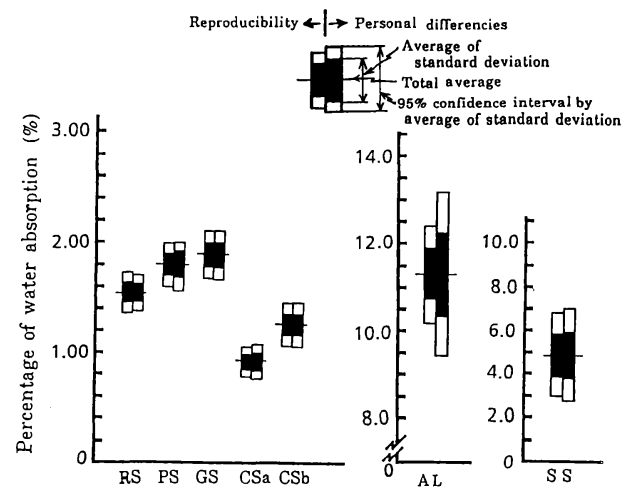

\begin{tabular}{|c|c|c|c|c|c|c|c|}
\hline $\begin{array}{l}\text { Kinds of } \\
\text { fine aggregate }\end{array}$ & RS & PS & GS & $\mathrm{CSa}$ & CSb & $\mathrm{AL}$ & sS \\
\hline Fineness modulus & 2.92 & 3.05 & 2.78 & 2.94 & 2.94 & 1.89 & 2.76 \\
\hline passing a $75-\mu \mathrm{m}$ & 1.04 & 1.76 & 1.80 & 0.80 & 5.70 & 3.33 & 0.97 \\
\hline
\end{tabular}

RS : River sand PS : Pit sand

AL : Artifical lightweight fine aggregate

CSb : Crushed sand (Type b)

Fig. 3 An example of percentage of water absorption by flow-cone method and its scattering.

用いた Table 1 に示される細骨材とほぼ同じものも含む が，生産ロットが異なっているので，粗粒率などの性状 值が若干異なる。

Table 2, Fig. 3 からわかるように, 繰り返し 6 回の 6 人分および 6 人による 6 回分の平均值についてのばらつ きを表わす標準偏差や $95 \%$ 信頼区間（1 回の試験值が $95 \%$ の確率で正常と判断される範囲）により, 再現性 によるばらつきおよび個人差によるばらつき（この場合 6 回繰り返しの 6 人による 6 回分の標準偏差の平均値で 表わされている) を比べると，洗い試験で失われる量の 多いもの,粒子の形状が稜角に富む砕砂やスラグ細骨材, 吸水率の高い人工軽量細骨材となるほど, 後者の標準偏 差が大きくなる傾向が認められるが人工軽量細骨材を除 いては，両者の差はわずかである.

しかし，ばらつきの值としては再現性や個人差とはや や性質が異なるが，JIS A 1109，および 1134 で示され る 1 回の試験（ 2 測定値を得る）の精度は 2 測定値の平 均値からの偏差で表わされ, その值は人工軽量細骨材で $0.10 \%$ ，それ以外の細骨材では $0.03 \%$ 以下之定められ ている. いま,この值と Fig. 3 で示したばらつきとを比 較すると再現性, 個人差とも非常に大きなばらつきがあ ることになる，一例を挙げればばらつきのうえで最も小 さい結果を示した川砂の再現性の場合でも, Table 2 で わかるように各自 6 回の平均値の 6 人分のばらつきです ら，それを数倍上回っていることになる。このことは, 一般に試験は絽り返しは行わないで 1 回の試験結果で表
わされるところから, Table 2 の中の $95 \%$ 信頼区間の 最大值と最小値とでみると Fig. 3 に示した平均値の標準 偏差から求めた幅よりもさらに広いものとなる.すなわ ち, 本例の川砂でも 1 回の試験で吸水率がおよそ 1.30 $\sim 1.86 \%$ 程度の範囲の結果が得られた場合に, その值 が異常であるとはいえず，フロー吸水率の再現性や個人 差のばらつきはこの程度生じてもやむを得ないものと思 われる.これが砕砂, スラグ細骨材, 人工軽量細骨材と なると，もっと大きなばらつきが生じている．この原因 として, フロー吸水率の試験での試料の調整において, 表乾状態の判定が非常に微妙であり, 再現性のばらつき や個人差がある程度介在することが避けられないとみら れ，試験結果のばらつきを大きくしていると考える.

また，本実験の試料についてもフロー吸水率と遠心含 水率の測定における個人差をみるため, コンクリートの 試験業務 3 年以上の経験者 7 人による測定結果を Fig. 7 に併記した。

この結果, フロー吸水率では人工軽量細骨材を除き, いずれの細骨材の場合でも, 7 人の測定者が各 1 回行っ た試験結果の標準偏差は $0.09 \sim 0.52 \%$ の範囲（これに は洗い損失量を人為的に取り除いた試料によるデータも 含むので，実際には最小値はもう少し大きな值と考えら れる) にあり, 山砂, 砕砂, スラグ砂が大きい値を示し ている.フロー方法を用いる JIS A 1109 による吸水率 の試験においては, 同一試料で $2 つ$ つ測定結果の平均値 からの偏差は $0.03 \%$ 以下と規定されていて，この試験 でもいずれの測定者においてもそれを満足しているが, しかし 7 人の測定者間の個人差は標準偏差でその 3 17 倍にも達していて Fig. 3 とほぼ同じ傾向を示している. いま，これらの個人差の $95 \%$ 信頼区間を求めてみると, 普通骨材では小さい区間幅の川砂においても $0.35 \%$ 程度であり，砕砂では士0.82％にも達するのもある. これらの区間幅からコンクリートの単位水量への影響を 試算すると, 前者で約 $3 \mathrm{~kg} / \mathrm{m}^{3}$ 前後, 後者で約 $7 \mathrm{~kg} / \mathrm{m}^{3}$ 前後の差が生ずることになり, 比重や吸水率はもとより 表面水率に与える影響も大きく，コンクリートの製造に おける水の計量誤差（計量値の土1\%すなわちコンク リートの単位水量にしておよそ $\left.1.5 \sim 2.0 \mathrm{~kg} / \mathrm{m}^{3}\right)$ より も大きな值となる．また，スラグ細骨材，人工軽量細骨 材ではさらに大きな值を示している.

\section{4. 遠心方法による表乾状態}

予備実験において 2,3 の試料を用いて脱水時間と遠 心含水率との関係 (以下, 脱水曲線) について, 遠心力 を変化させて求めた結果から, Fig. 4 に示す A, B, C の 3 つのパターンの脱水曲線に大別される. 曲線 $\mathrm{A}$ は曲 線 Bに比べやや低い遠心力を用いた場合で，脱水時間の 


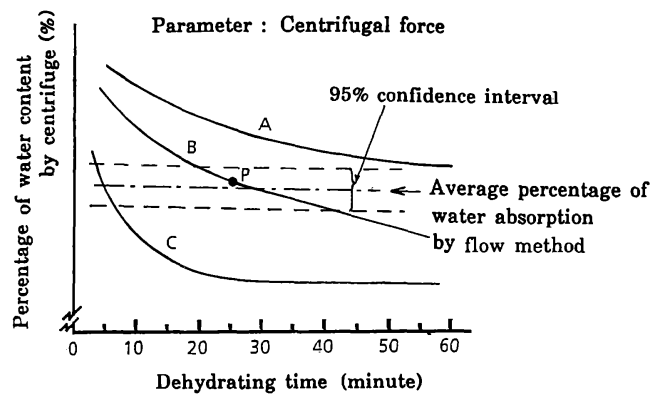

Fig. 4 Pattern of dehydration curve.

経過に対して曲線的な含水率の減少を示しているもの で, しかも脱水時間が 60 分程度では, その遠心含水率 はフロー吸水率に比べて高い值となっている.

一方, 曲線 Cのように遠心力を曲線 Bに比べて, かな り高い值を用いると, 急速に含水率が低下しある時間以 降で含水率はほぼ平衡状態に達する. しかしその平衡状 態の含水率はフロー吸水率よりは小さな值となる.

これら曲線 $A, C$ に比べて曲線 $B$ は脱水時間の経過と ともに曲線的に含水率が低下する傾向は, 曲線 $\mathrm{A}, \mathrm{C}$ と も類似した傾向にあるが，ある時間以後は含水率の低下 がほぼ直線変化となる傾向が認められ, 個々の細骨材の 脱水曲線での曲線と直線との接点 $\mathrm{P} て ゙$ 表わされる脱水時 間における遠心含水率がフロー吸水率の平均值に近似す ることがわかった。

なお，人工軽量骨材では骨材内部の間隙が普通骨材な どの毛管間隙よりも相当に大きな気孔を有していること から，大きな遠心力では骨材内部の気孔中の水が脱水さ れるので比較的小さな遠心力を用いることが必要となる が, 同じような傾向が認められた。

そこで遠心方法により細骨材を表乾状態に調整するに は, P点の含水率がフロー方法の吸水率に近似する脱水 条件を定めればよいこととなる。

ところで表乾状態とは，JIS A 0203 によれば「骨材 の表面水がなく骨材粒の内部の空隙が水で満たされてい る状態」と定められている. すなわちフロー方法は細骨 材粒子が表面水を有する状態から乾燥により粒子表面の 自由水が零となり，凝集力を失う瞬間の状態を判定する 方法であるとされている.これを確かめるために，吸水 率 $0 \%$ の細骨材としてガラスビーズおよび破砕ガラス 粒を最大粒径 $5 \mathrm{~mm}$, 最小粒径 $74 \mu \mathrm{m}$, その粒度分布が 標準粒度範囲（JIS A 5308 付属書 1.3 土木用骨材）の ほぼ中点を通る粗粒率 2.75 の細骨材を作成し, 実験を 行った結果を Table 3 に示す.

これによれば表面がなめらかで球状のガラスビーズの 場合には吸水率がほぼ 0 となり, 表面に水の存在しない 表乾状態であるが，これに対して破砕ガラス細骨材では
Table 3 Percentage of water absorption by flow method.

\begin{tabular}{c|c|c}
\hline Type & $\begin{array}{c}\text { Glass - bead } \\
\text { fine aggregate }\end{array}$ & $\begin{array}{c}\text { Crushed glass } \\
\text { fine aggregate }\end{array}$ \\
\hline $\begin{array}{l}\text { Percentage of water } \\
\text { absorption by flow } \\
\text { method (\%) }\end{array}$ & 0.01 & 0.30
\end{tabular}

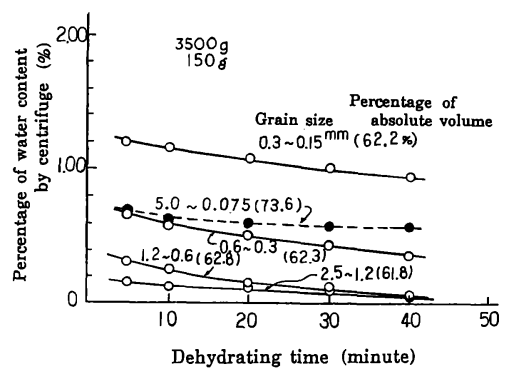

Fig. 5 Dehydration of glass-bead.

表乾状態であっても表面水 (以下いわゆる表面水と区別 するため付着水とよぶ）が存在していることになる。こ れはガラスの破砕面に生じた粗面のため水膜厚さが一様 でなく凸部が乾燥しても凹部では乾燥されずに水が吸着 されていて, しかもその水が粒子の凝集力を発生させな ければ，すなわち粒子の接点に水の存在がなければフ ロ一試験では表乾状態と同じ結果となることによるとみ られる.

このことからフロー法で求めた表乾状態は, JIS A 0203 で定義される状態とは表面が滑らかな球状粒子以 外の場合に，一致していないといえる.

これに対して遠心方法では表面水の大半は遠心力の作 用により脱水されるものの粒子の接触部に存在する水は 完全に離脱し得ず拘束水 ${ }^{5}$ として残る.これが結果的に $\mathrm{P}$ 点で遠心含水率とフロー吸水率が近似したものとみら れる.

この拘束水の存在を確かめるために, 先に示した吸水 率 $0 \%$ の粒子としてのガラスビーズを用いた実験結果 を Fig. 5 に示した。これによればガラスビーズの粒度分 布を調整した実積率の高い場合や, 粒子径の小さい単粒 度分布の場合には拘束水の残留が多くなり（粒子間に毛 管間隙が多くなったとみなせる)遠心含水率が大となる. しかし逆に粒子径を大きくして単粒度分布にし実積率を 下げると, 拘束水はほとんど存在しなくなる.すなわち, 遠心含水率は $0 \%$ に近くなる。

これらのことから遠心脱水によって得られる表乾状態 に基づく吸水率は, フロー方法で残っている付着水と拘 束水とがバランスするところを選ぶことにより, フロー 方法による表乾状態に基づく吸水率に近似させることが できる.拘束水を除去するためにより遠心力を高めると， フロー吸水率よりも遠心含水率の方が小さくなるが, そ の方が定義にいう表乾状態に近いことになる. 


\section{5. 遠心力および遠心脱水時間と遠心含水率と の関係}

P点の得られる条件として普通細骨材 (川砂, 山砂), および砕砂 ( 2 産地分), スラグ細骨材の場合には遠心 力を $3000 \mathrm{~g}$ および $3500 \mathrm{~g}$, 試料質量を $150 \mathrm{~g}$, および $200 \mathrm{~g}$ ，また人工軽量細骨材の場合には遠心力 $100 \mathrm{~g}$, $200 \mathrm{~g}, 300 \mathrm{~g}$ および $400 \mathrm{~g}$, 試料質量を $150 \mathrm{~g}$ により求 めた脱水曲線を Fig. 6 に示す.

これらの図から普通細骨材では，上記のいずれの遠心 力および試料質量の組合せにおいても，遠心脱水時間が 2 分間程度までの間に急速に脱水され，およそ 10 分間 以後の遠心含水率の変化は小さくなるとともに，その後 脱水時間が 20 分前後で Fig. 4 のB曲線で示したように
含水率の変化はほぼ直線に移行することがわかる．この 各細骨材の脱水曲線が曲線から直線に移行するP点が脱 水条件に応じて求められる.

この結果, 普通細骨材, 砕砂, スラグ砂ともに洗い損 失量の少ないもの (基準値の $1 / 2$ 以下程度すなわち, 普 通細骨材で $1.5 \%$ 前後, 砕砂, スラグ砂で 4 〜 $\%$ 以下) では，遠心力 $3500 \mathrm{~g}$, 試料質量 $150 \mathrm{~g}$ の条件で脱水時 間が 15 分前後にP点が位置しており，その遠心含水率 もフロー吸水率の平均值にほぼ近似する.これに対して 洗い損失量の多い場合（基準の限界値付近すなわち，普 通細骨材 (山砂) で $3 \%$ 前後, 砕砂で $7 \%$ 前後）には, 同じ遠心力, 試料質量の条件でも, Fig. 6 からわかるよ うにP点にあたる遠心含水率がフロー吸水率の平均值と 若干異なる值を示すものもある.しかしその差は小さい.
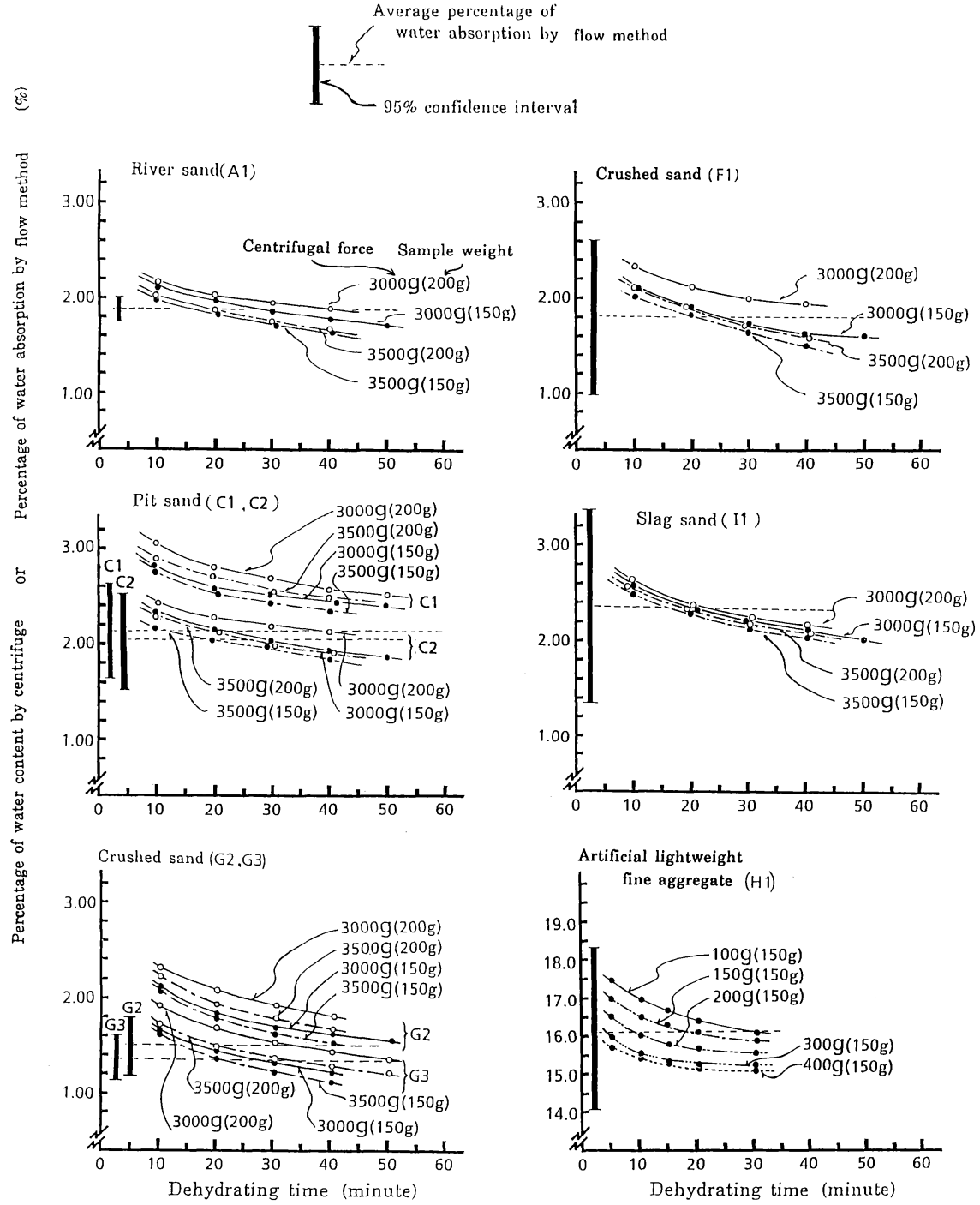

Fig. 6 Dehydrating curve in each fine aggregate.

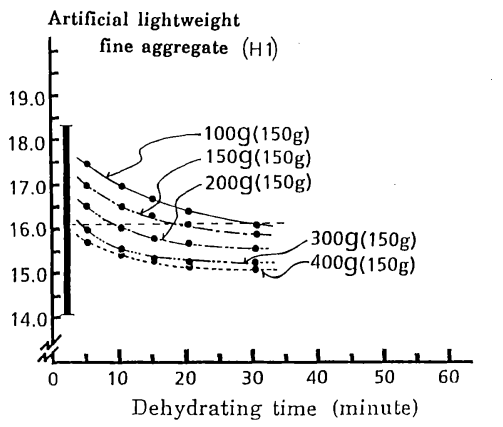


したがって普通骨材を始め砕砂，スラグ細骨材において も，細骨材中の洗い損失量が基準值の上限にあたる場合 でも， $\mathrm{P}$ 点の遠心含水率を表乾状態の吸水率とみなして 差し支えないものと考える，実際には細骨材の種類が変 わるごとにP点を求めることは繁雑であり, 試験方法と してはできるだけ条件が一定であることが好ましいこと 加，普通細骨材 (川砂，山砂等)，砕砂の場合には脱 水条件を遠心力 $3500 \mathrm{~g}$, 試料重量 $150 \mathrm{~g}$, 脱水時間 20 分とし，スラグ細骨材の場合には同様に $3000 \mathrm{~g}, 150 \mathrm{~g}$, 20 分, また人工軽量細骨材では粒子内の細孔径が大き いため遠心力は小さくてょく, 同様に $150 \mathrm{~g}, 150 \mathrm{~g}, 20$ 分で表乾状態の試料が得られることになる.

以下，上記の脱水条件で求めた遠心含水率を特に遠心 吸水率とよぶ。

\section{6. フロー吸水率と遠心吸水率の個人差につい て}

フロー吸水率と遠心吸水率との個人差を比較するた め, a) で決めた条件で求めた遠心吸水率とフロ一吸水 率との対比を Fig. 7 に示した。

この結果，普通骨材においては洗い損失量が JIS 基 準値の約 $1 / 2$ のものでは，遠心吸水率とフロー吸水率の 平均值が近似するが，洗い損失がそれを越えるとその差 が少し生じる．砕砂では基準值の $2 / 3$ の場合で両方法の 吸水率の平均值に若干の差がみられるが，他の場合には ほぼ近似している．また，スラグ細骨材，人工軽量骨材 の場合にはよく近似している.

さらにいずれの場合にも，遠心吸水率の $95 \%$ 信頼区 間はフロー吸水率の $95 \%$ 信頼区間の幅の中にほとん亡゙ 含まれ，しかもその幅はフロー吸水率の幅に比べて著し く小さく，個人差の少ないこと，すなわちより安定した 表乾状態の試料調整方法であることが認められる。

また，個人差が最も大きく現われやすいとみられる砕 砂を用いて洗い損失量を変えて行った実験結果を Fig. 8 に示す。

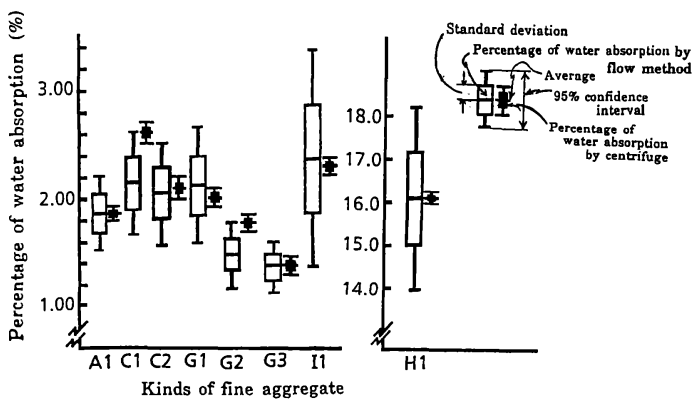

Fig. 7 Comparison of scattering on percentage of water absorption.

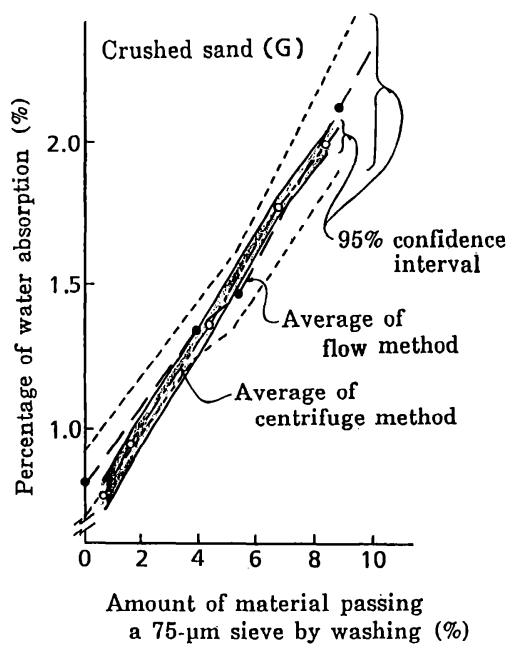

Fig. 8 Scattering of amount of material passing by washing and percentage of water absorption of crushed sand.

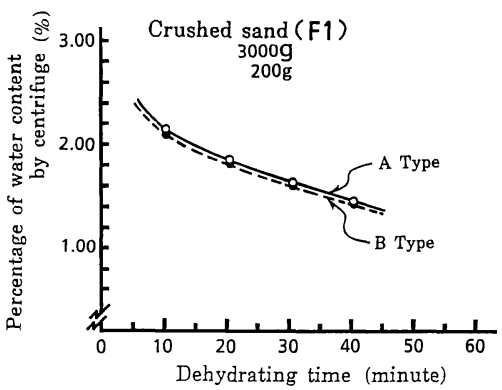

Fig. 9 Types of filter cloth and percentage of water content by centrifuge.

この結果から明らかなように，フロー吸水率では洗い 損失の量が増すに従って $95 \%$ 信頼区間の幅の広がりが みられるのに対し，遠心吸水率では区間の幅は洗い損失 量が増しても変わらず，かつフロー吸水率の区間の幅に 比べて $1 / 2 \sim 1 / 4$ 程度と精度の良いことが明確である.

\section{7. 沪布の種類と遠心含水率}

Fig. 9 に 2 種類の沪布を用いた結果を示したが，この 図より 2 種類の沪布の間には特に差は認められなかっ た。

この結果から，本実験に用いた沪布とあまり差のない 品質の沃布であれば，同様の結果が得られるものと判断 される。

\section{8. まとめ}

（1）遠心脱水機を用い，適度の遠心力を与えて脱水 を行った場合の細骨材の脱水曲線において，曲線から直 線に転じる脱水時間における遠心含水率が，JISによる フローコーンで求めた吸水率に近似することを見出し 
た.これにより遠心脱水機を用いて細骨材の試料の表乾 状態の調整を，機械的に行うことができる.

（2）実用的には脱水曲線の転移点をその都度求めな くとも, 普通骨材, 砕砂の場合の脱水条件を遠心力 $3500 \mathrm{~g}$, 試料質量 $150 \mathrm{~g}$ ( 1 カップ当たり), 脱水時間 20 分，スラグ細骨材の場合は同じく $3000 \mathrm{~g}, 150 \mathrm{~g}, 20$ 分, および, 人工軽量細骨材の場合は同じく $150 \mathrm{~g}, 150 \mathrm{~g}$, 20 分の条件によりフロー吸水率に近似する吸水率の状 態すなわち表乾状態とすることができる.

（３）この方法を利用することにより各種細骨材の表 面水率を迅速かつ正確に求め得る.

なお, 生コン工場の工程管理では, 細骨材の表面水率 を求めるのに比重試験ほどの精度を要しないので, 簡易 迅速方法として上記（2）で示したよりも大きい遠心力 を用いてあらかじめキャリブレーションにより吸水率に 一致する脱水時間を求めておけば，より短時間で表面水 率を測定することができる.

（4）付随的な問題であるが, JIS A 5004「コンクリー 卜用砕砂」では砕砂の表乾状態への調整の際に 0.15 $\mathrm{mm}$ ふるいで水洗いを行った試料で行ってもよいとして いるが，本研究で示したように，0.074 mmで水洗いを 行った試料を用いると吸水率の值は大幅に小さくなると
ころから，コンクリートの配合設計における有効水量の 考え方に与える影響も少なくない. 今後表乾状態でも表 面に水が存在していることおよび, 表乾状態の試料調整 は任意の洗い損失量で行うのか, 水洗いした試料で行う のか, 砕砂以外の細骨材を含めて検討の必要があるもの と考える.

\section{参 考 文 献}

1）吉兼 亨・鯉江利夫・中島佳郎：遠心脱水機を利用した 細骨材の吸水率, 表面水率について, 第 2 回生コン技術 大会論文集, 全生工組連, pp. 135 140, 1983 年.

2) 吉兼 亨・鯉江利夫 - 中島佳郎：遠心脱水による細骨材 の表面乾燥内部飽水状態について, セメントコンクリー ト, セメント協会, No. 444, pp. 40 47, 1984 年 2 月.

3）伊東靖郎：細骨材の水と空気による界面状態がコンク リートおよびモルタルに及ぼす影響に関する研究，土木 学会論文報告集, 第 343 号, pp. 229 238, 1984 年 3 月.

4）辻 幸和・二羽淳一郎・伊東靖郎・岡村 甫：遠心力を 利用した細骨材の保有水試験方法, 土木学会論文集, 第 384 号 $/ \mathrm{V}-7$, pp. 103 109, 1987 年 8 月.

5）箭内寛治・飯竹重夫：講座 4. $\mathrm{pF}$ の原理と応用, $\mathrm{pF}$ の 工学的応用 (その 1 ), 土之基礎, 土質工学会, No. 349, pp. 99〜105, 1987 年 2 月.

(1987.12.21 • 受付) 